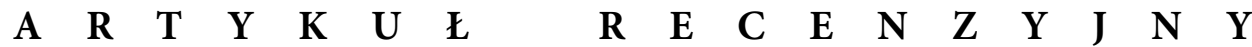

„Etnografia Polska”, t. LXV, 2021, z. 1-2

PL ISSN 0071-1861; e-ISSN: 2719-6534

DOI: $10.23858 /$ EP65.2021.2902

CC BY 4.0

\author{
JERZY S. WASILEWSKI
}

Instytut Etnologii i Antropologii Kulturowej UW, Warszawa

\section{MIĘDZY SPRAWCZOŚCIĄ A WYKORZENIENIEM. ETNICZNE REAKCJE NA OBRZEŻACH CHIŃSKIEJ HEGEMONII}

Chiński impakt w skali globalnej, czy to w postaci wszechobecności produktów na rynkach całego świata, czy gigantycznej inicjatywy finansowej Pasa i Drogi (Nowy Jedwabny Szlak), czy wreszcie miękkiej ekspansji kulturalnej obok niekoniecznie miękkich działań politycznych i militarnych - wszystko to jest przedmiotem wielodziedzinowych studiów i refleksji, także akademickich. Wymienione elementy składają się przecież na obraz Chin jako najpoważniejszego gracza, dążącego do zmiany sytuacji na międzynarodowej szachownicy (w proporcji do prawie dwudziestoprocentowego udziału własnego w światowej wytwórczości dóbr), aż po przejęcie globalnego przywództwa. W tej perspektywie patrzy się z niepokojem na działania państwa chińskiego w obszarze polityki krajowej, zwłaszcza takie jak zaawansowana inwigilacja społeczna $\mathrm{z}$ wykorzystaniem wiodących technologii elektronicznych, masowy nadzór poprzez punktowy system zaufania społecznego czy kwestie respektowania praw człowieka; budzą one głębokie obawy z racji ich kolizyjności wobec tradycji i deklaracji Zachodu.

Dla etnologów szczególnie interesujące jest zagadnienie stosunku do mniejszości etnicznych. W prowadzonej przez władze ChRL polityce wobec 55 grup etnicznych (minzu) zachowanie właściwych proporcji między kijem a marchewką to kwestia absolutnie zasadnicza, choćby zważywszy na lekcję, jaką stanowił przypadek radziecki - rozprucie się imperium właśnie po szwach etnicznych. Oceny obserwatorów mają oczywiście charakter subiektywny, wcale nie bezstronny, czasem propagandowy. Nasza dyscyplina, z wyczuleniem na kwestie mniejszościowe z jednej strony, a z niechęcią do formułowania sądów absolutyzujących, niezrelatywizowanych z drugiej, zapewne mogłaby wnieść takie obserwacje, które wymykałyby się z owej interesownej subiektywności czy stronniczości. Na ile badacze są w stanie wyważyć racje, wyjść poza traktowanie Chin jako postkomunistycznego „czarnego luda”, nie będąc jednocześnie ślepymi na autorytaryzm władzy czy etniczną hegemonię Hanów? Czy potrafimy zrezygnować $\mathrm{z}$ utrwalonych w europejskiej świadomości fantomów czy fantazmatów, np. zmistycyzowanej wizji Tybetu jako kraju głębokiej duchowości, obserwując upodobnianie się Lhasy do chińskich metropolii albo procesy odgórnej sedentaryzacji pasterzy-nomadów? A jak ocenimy buldożerową przebudowę starych ujgurskich miast i osad - $\mathrm{w}$ jakim stopniu uznamy to za niszczenie miejscowej tkanki kulturowej, a w jakim za pożądaną modernizację, skoro sami ich mieszkańcy mają tu mieszane uczucia? Bo przecież to samo odbywa się także w Pekinie - pod radosnym hasłem „harmonijnego wyburzania” (héxié chāiqiān).

Nie przypadkiem przywołuję te dwa miejsca: Tybet (w znaczeniu kulturowym, czyli Tybetański Region Autonomiczny wraz z tybetańskimi obszarami prowincji sąsiednich) oraz Sinciang („nowe kresy" - oficjalnie Region Autonomiczny Sinciang-Ujgur albo też, jeśli użyć starej a nieakceptowanej w ChRL nazwy, Turkiestan wschodni). Chiny w swej drodze na zachód mają przecież w obrębie własnej państwowości te dwa obszary, które poddają szczególnej presji: cywilizacyjnej, ekonomicznej, politycznej. Regiony te, może marginesowe w skali globalnej, są ważne strategicznie, a też i niełatwe z powodu swej radykalnej odmienności etnokulturowej od przygniatającej hańskiej większości; w skali 
Państwa Środka to one są najbardziej problematyczne (na trzeciej pozycji, ale w znacznym oddaleniu, wypada umieścić Mongolię Wewnętrzną, co praktycznie wyczerpuje listę możliwych turbulencji). Chociaż stopień konfliktogenności bywa różnie szacowany, to można zasadnie stawiać pytanie, czy stosowane przez władze środki będą działać stabilizująco czy raczej zaowocują długoterminowo kolejnymi niepokojami etnicznymi. Jeśli wolno mi sparafrazować Noblistkę: „Narody małe rozumieją mało, generale Wang" - czy takie hasło będzie kierować polityką chińskiego hegemona?

Zwróćmy uwagę na przytoczone powyżej pojęcie harmonii, héxié, pojawiające się jako oficjalnie deklarowana intencja polityczna. Ta odwieczna chińska idea, jeszcze konfucjańska, została przekuta przed kilkunastoma laty przez ówczesnych przywódców w ideologię „harmonijnego społeczeństwa”, héxié shèhuì, co miało oznaczać łagodzenie efektów dysharmonijnego bogacenia się (nieproporcjonalnego także w wymiarze etnogeograficznym) poprzez odgórne akcje afirmatywne, wyrównawcze. Dziś wahadło wychyliło się w stronę autorytaryzmu, więc hasło to zastąpił twardziej brzmiący postulat „Zachowania stabilności”, weiwen. Zaostrzenie to było szczególnie dramatyczne w ujgurskim Sinciangu, co akurat dla działających tam przedstawicieli naszej profesji oznaczało koniec swobodnych badań terenowych. Tak więc obraz, o którym będzie tu mowa w oparciu o niedawne publikacje, dociera do nas niejako z przeszłości, wydłużonej jeszcze przez proces wydawniczy - ten etnograficzny praesens to zatem koniec pierwszej dekady (i początek drugiej) obecnego stulecia. W tym sensie nie są to zatem odpowiedzi na najbardziej aktualne wątpliwości i obawy.

Niezależnie od politycznej oceny dziejących się i wtedy, i dziś procesów sinizacji, kontrolowania i podporządkowania, odwiedzający oba te obszary badacze mają okazję przyjrzeć się temu, jak chińskie presja realizuje się w skali lokalnej, przekładając się na zmiany wśród rdzennych społeczności. Etnografowie lepiej niż ktokolwiek inny rozumieją wadliwość patrzenia jednostronnego i wiedzą, iż z samej natury rzeczy są to wpływy i przepływy dwukierunkowe: nie tylko uleganie presji zewnętrznej i wszelakim importom, ale też własne wychodzenie na zewnątrz, czy przynajmniej otwarcie na chińskie zapotrzebowanie i aktywność w jego zaspokajaniu.

Warto w tym kontekście przybliżyć dwie z niedawno wydanych anglojęzycznych publikacji dotyczących tej problematyki, w ujęciu zdecydowanie etnograficznym, „od dołu” i w detalu - choćby ze względu na związek Autorów (Autorek) z polską etnologią. Pierwsza z nich, książka Emilii Róży Sułek Trading Caterpillar Fungus in Tibet. When Economic Boom Hits Rural Area (Sulek 2019) stanowczo zbyt długo czekała na recenzję w kraju - może z racji paradoksalnego połączenia szczegółowej kwestii pewnego egzotycznego grzyba z szerokim antropologicznym zakrojem, a wszystko to w odniesieniu do mało komu znanego terenu. Z prawdziwie etnograficzną wnikliwością przedstawia ona te wszystkie okoliczności, które towarzyszą nieznanej wcześniej (na taką skalę) eksploatacji - wyłącznie na potrzeby chińskie - pewnego, słynnego już dziś, grzyba. Maczużnik chiński (Ophiocordyceps sinensis, tyb. yartsa gumbu), czyli „zimą trawa, latem robak” - ten mizernej wielkości entomofag wyrasta z uśmierconej przezeń gąsienicy, tworząc wespół z nią całość. Jego niebanalna natura zapewniła mu miejsce w chińskiej farmakopei. I to właśnie chińskie, a nie tybetańskie zapotrzebowanie uruchomiło w latach 90. niebywały wzrost cen, masową, wielotonową jego eksploatację (nie jest ona niczym trudnym), a w konsekwencji - finansową bonanzę i daleko idące przeobrażenia w życiu zbierających go pasterzy.

Zaryzykuję stwierdzenie, że dzięki tej książce (co zaskakujące, pierwszej w ogóle mu poświęconej!) maczużnik dołączył do grona tych grzybów, które mocno zaistniały w etnologii, zajmując miejsce obok japońskiego matsutake - odkrycia Anny Lowenhaupt Tsing (2015) oraz halucynogennego muchomora jako domniemanej somy, co pokazał swego czasu Robert Gordon Wasson (1972).

Wprawdzie tytuł mógłby zwiastować raczej ekonomiczne studium mechanizmu rynkowego, to książkę pisała etnografka, absolwentka warszawskiej etnologii i mongolistyki (z tybetologią). Jej monografia to dużo więcej niż opracowanie przepływów handlowych ujętych w ramy rynku. Szukając określeń oddających kompleksowy charakter pracy, autorka sięga po klasyczne terminy: „opis gęsty”, „całościowy fakt społeczny”. I nie są to sformułowania na wyrost - czytając pracę, widzimy, jaka siatka powiązań łączy ów grzyb z wieloma obszarami życia; bytowanie tybetańskich pasterzy stoi pod znakiem poszukiwania go i handlu nim, a suma zmian, jakie wniosła grzybowa ekonomia 
w ciągu paru dziesiątków lat, radykalnie przekształciła obraz ich życia, w tym ich wizerunek samych siebie. Co więcej, zważywszy na bardzo oddolny, a przy tym nie całkiem legalny charakter części praktyk notowanych przez autorkę, praca wkomponowuje się w nurt antropologicznych badań „szarej gospodarki", przebojowo zainicjowany swego czasu przez znakomite studium Tomasza Rakowskiego (2009); ich rozwinięciem w odniesieniu do realiów mongolskich jest też ostatnia publikacja tego Autora (2019). W omawianej książce również mamy do czynienia $\mathrm{z}$ badaniem niestandardowych przejawów aktywności na obszarach marginalnych, z obserwacją z bliska różnych żywiołowych, emergentnych form znajdowania środków utrzymania. Pozwolę sobie zatem zasugerować, że podtytuł krajowej wersji omawianej pozycji mógłby brzmieć Studium sprawczości szemranej.

Jako że polskiego tłumaczenia zapewne jednak nie będzie, praca zasługuje na szersze przedstawienie, albowiem ze względu na swój całościowy charakter i metodyczność opracowania może posłużyć za wzór dla rozpraw doktorskich i habilitacyjnych. Sama jest pokłosiem doktoratu na berlińskim Uniwersytecie Humboldtów, a ten „urzędowy” charakter uwidacznia się miejscami w postaci takich cech tekstu, jak uważność w definiowaniu przyjmowanych pojęć, skrupulatne roztrząsanie i kolejne wyliczenia stosownych argumentów i alternatyw, staranie o akuratność ocen i precyzję sądów. Są też tabelki ze statystyką - trzeba docenić te pracowicie zbierane dane ilościowe, wiedząc, że nie są to liczby łatwo przepisane z urzędowych zestawień. Jak zobaczymy, jest to jeden z licznych elementów świadczących o ilości i jakości włożonej w to dzieło etnograficznej pracy terenowej.

Jego bohaterami są Golokowie, grupa tybetańska zamieszkująca w prowincji Cinghaj (czyli poza autonomicznym Tybetem), słynna niegdyś ze swych rozbójniczych napadów na karawany i podróżników. Kraina Golok stanowi jeden z obszarów najbardziej intensywnego występowania maczużnika, który rośnie też w innych partiach Tybetu i w Himalajach. Autorka spędziła tam, na wysokościach powyżej 4 tys. m n.p.m., rytualny dla badań rok (choć podzielony, zgodnie z wymogami wizowymi), mieszkając z rodzinami żyjącymi w górskim oddaleniu. Jeździła także (np. na użyczonym motocyklu) po szerszym terenie kilku gmin, wizytując większe miejscowości (aż po stołeczny Xining i jego apteki), gdzie odbywa się ów tytułowy handel. W tekście stale przewijają się świadectwa upewniające czytelnika, że udało się jej osiągnąć dużą zażyłość i wgląd w całokształt życia, niegdyś prawie wyłącznie pasterskiego, a dziś zogniskowanego wokół monokulturowego zbieractwa - właśnie owego lukratywnego grzyba yartsa. Przemyślany układ pracy dobrze oddaje jego promieniowanie na wszystkie sfery pasterskiego działania.

Pierwsze roztrząsania mają charakter definicyjny: autorka przekonuje nas, że głównych terminów nie wolno używać bezrefleksyjnie. Takie pojęcia, jak „rozwój”, „modernizacja” czy „nowoczesność” wcale nie są ani jednoznaczne, ani bezproblemowe, będąc raczej płynącymi z rządzącej góry programami, wdrażanymi wobec regionów uznanych przez ową górę za „nierozwinięte” i „nienowoczesne”. W odniesieniu do zbierania (a ściśle „wykopywania”) grzybów taką odgórną nowoczesnością byłoby np. zakazywanie go w imię racji ekologicznych (oznacza ono bowiem masowe rozkopywanie górskich pastwisk) czy politycznych (bo jest to niekontrolowane, nieopodatkowane zarobkowanie), zacofaniem zaś - odwrót od wysokotowarowej gospodarki pasterskiej (hodowla jaków na mięso, mleko i sery) na rzecz prymitywnego, acz znacznie bardziej dochodowego, zbieractwa i pokątnego handlu yartsa.

Autorka w całej pracy daleka jest jednak od czarno-białego obwiniania władz o autorytarną politykę kontrolowania i zakazywania, wobec której pasterze mieliby być jedynie ofiarami. Przenosząc metaforycznie obraz grzyba pasożytującego na gąsienicy, pyta, który z tych dwóch podmiotów społecznych jest kim i odpowiada, że pozycje są tu wymienne. Lokalne władze osiągają założony cel modernizacyjny, przymykając oko na nie całkiem legalną eksploatację, albowiem zyski z niej i tak się ujawniają (poprzez zakupy i inwestycje), co zatem w ostatecznym rachunku doprowadza do odgórnie zaplanowanej poprawy warunków życia; z kolei gdy to pasterze chcą osiągnąć swój cel i stawić opór odgórnej kontroli, efektywnie korzystają z arsenału „broni słabych” (James C. Scott) zwlekania, unikania itp.

U podłoża badań leżała intencja uwypuklenia sprawczości Goloków, dla których zmiana dotychczasowego trybu życia nie jest tragedią, a tylko aktywną transformacją. Pytania oscylowały wokół 
kwestii: co oni robią dla zdobycia pieniędzy i co robią z tymi pieniędzmi - ale też: co one robią z nimi. Aktywność pasterzy wyraża się $\mathrm{w}$ osobistym udziale w sezonowym zbieraniu yartsy, jak również w praktykach ukrywanego przed władzami wydzierżawiania grzybonośnego terenu przynależnego danej rodzinie dużym grupom zbieraczy przybyłych na ten czas z Chin. Pobierane z tego tytułu opłaty kilkakrotnie przekraczają sumy uzyskane w rodzinie z własnoręcznego kopania (nie mówiąc już o hodowli), składając się na naprawdę poważne kwoty, rzędu dobrych kilkuset tysięcy juanów rocznie. Badaczka przyglądała się relacjom między pasterzami odnajmującymi swoje grunta i pomieszczenia mieszkalne a chińskimi (i innymi obcymi) zbieraczami - poniekąd ich gośćmi. Wypracowawszy sobie znakomite relacje z rozmówcami, mogła liczyć na szczegółowe relacje na temat dysponowania pieniędzmi, nawet $\mathrm{w}$ dyskretnej materii wysokości tych finansów.

Dociekliwie przeprowadzała czasochłonne ankiety domowych finansów - w sumie pięćdziesięciu gospodarstw, dokumentujące liczbowo imponujący wzrost zamożności, którego kulminacją jest budowanie lepszych domów, porzucanie namiotów i przechodzenie na coraz bardziej osiadły tryb życia. Wypada tu zwrócić uwagę na pewien paradoks: choć grzybowe wzbogacenie jest widoczne gołym okiem, to przecież jego mechanizm należy do wspomnianej szarej strefy gospodarowania. Tak więc badaczka musiała niekiedy poprzestawać na wiadomościach trudno sprawdzalnych; mogę przypuszczać, że tu i ówdzie była skazana na poruszanie się w obszarze wiedzy niepewnej i formułowanie wniosków mimo wahań i wątpliwości.

Wyczulona na kwestię kobiecej sprawczości zwróciła uwagę na mało „upłciowiony” charakter samego kopania yartsy: choć światową regułą jest przypisanie zbieractwa kobietom (przypomnijmy dawne, oprotestowywane zresztą, sformułowanie Man the Hunter, Woman the Gatherer), w wypadku tego akurat zbierania jego lukratywny charakter powoduje, że i dla mężczyzn nie stanowi ono zajęcia poniżej ich godności. Niemniej, chociaż ostatecznie większość środków finansowych, pozyskanych z grzybowej hossy trafia do mężczyzn, to - jak pokazuje autorka - sprzyja ona finansowej emancypacji kobiet, które nareszcie (po raz pierwszy?) mają dostęp do własnej gotówki i to zupełnie poza męską kontrolą - zawsze przecież mogą schować parę cenniejszych sztuk za pazuchę tybetańskiej szuby.

Yartsa - zauważa celnie autorka - nie jest dla Tybetańczyków lekarstwem, ale towarem. W przeszłości nie była całkiem nieznana, a zbieractwo roślin istniało tam od zawsze, jednak ta „gorączka złota" rozpoczęła się całkiem niedawno, za sprawą Chińczyków. Dlaczego właściwie maczużnik zdobył sobie nagle taką pozycję w chińskim, nazwijmy to, imaginarium farmakologicznym? Autorka wylicza cząstkowe odpowiedzi, powołując się na obserwatorów zmian w Chinach: wzrost postaw konsumenckich wśród rodzącej się klasy średniej, ustalenia nowoczesnej farmacji, sukcesy dopingujących się tym specyfikiem chińskich sportowców. Sama nie wchodzi jednak badawczo w temat, świadoma, że wymagałoby to znajomości zupełnie innych realiów - tego, co się działo poza „jej” Tybetem (wobec pasterzy wystrzegała się podejrzeń o jakikolwiek związek z Chinami, w tym o znajomość języka), np. na wielkomiejskim rynku, i to nie farmaceutyków, ale raczej wszelkich dóbr luksusowych i prestiżowych. Rozpoznanie tych zjawisk wymagałoby przecież czegoś w rodzaju studying up, by przypomnieć termin Laury Nader - badań „od etnografa w górę”, a też i „w bok”: środowisk biznesowych i elit władzy, czyli finansowych beneficjentów chińskiego przełomu. Trzeba by np. wiedzieć, na ile zadziałała tu atrakcyjność yartsy jako zamiennika Viagry (nota bene Tybetańczycy korzystają tu z okazji do odegrania się na Chińczykach: „my tego nie potrzebujemy” - tłumaczyli ze śmiechem badaczce; skądinąd, o ile mi wiadomo, takie jest też chińskie stereotypowe wyobrażenie na temat tybetańskiej potencji). Należało by rozpoznać niedostępne praktyki budowania znajomości guangxi, „okazywania wdzięczności", prezentów i korupcji, w których donchong xiacao (potocznie chongcao) jest osadzony; niezbędne byłoby monitorowanie mediów, reklamy itp. Wszystko to czytelnik musi sobie dopowiedzieć, nawet ryzykując pewien sensacjonizm, którego świadoma jest autorka, przytaczając gazetowe fajerwerki: „himalajska Viagra”, „lekarstwo na raka”, „mafia, przemyt, przestępczośc” itp.

$\mathrm{Na}$ kolejnych stronach znajdziemy przedstawienie lokalnego małomiasteczkowego rynku, na który trafia zebrana yartsa, dając sezonowe zatrudnienie istnej rzeszy ludzi wszelkiego autoramentu. Autorka charakteryzuje aktorów rynkowej gry, którymi są w większości przedstawiciele obcych grup 
etnicznych: Chińczycy Han i Huei oraz Salarowie; dwie ostatnie grupy, zdecydowanie tu dominujące, to muzułmanie, co daje tybetańskim sprzedawcom asumpt do utożsamiania całej tej sfery handlu $\mathrm{z}$ wyznawcami islamu. Zważywszy na różne konfliktowe doświadczenia w przeszłości, nie są to stosunki bezproblemowe, ale też, jak to ocenia autorka, ostatecznie to rynek i jego prawa mają głos decydujący.

Badaczka dostrzega niedogodną pozycję, w jakiej znajdują się nieliczni kupcy tybetańscy, od których sprzedający rodacy oczekują etnicznej lojalności, czyli wyższych cen zakupu, w efekcie czego „ekonomia moralna” działa na ich niekorzyść. Analizuje dylematy i strategie pasterzy, którzy bezustannie muszą decydować: sprzedać wcześniej czy później, małymi porcjami czy hurtowo, w postaci świeżej czy wysuszonej, naturalnej czy oczyszczonej, mieszając czy rozdzielając grzyby różnej wielkości/jakości. Opisuje przebieg obserwowanych z bliska transakcji, w tym oryginalny system bezgłośnego negocjowania ceny przez wzajemne ściskanie palców w zasłoniętych przed obcymi dłoniach. Chodzimy wraz z nią po byle jakich uliczkach, po prywatnych mieszkaniach, spelunkowatych lokalikach i skromnych sklepikach bez żadnego towaru, w których odbywają się łańcuszkowe transakcje. W sumie udaje się jej uzyskać niesłychanie dynamiczny obraz rojącego się ula, w którym yartsa krąży bezustannie, nie tylko przechodząc przez mnóstwo rąk, ale też goszcząc w wielu umysłach jako przedmiot bezustannych kalkulacji: spekulacji cenowej, gry na sezonową zwyżkę i zniżkę, przewidywań fluktuacji na rynkach zbytu, sięgających Hongkongu czy olimpiady w Pekinie.

W dalszych partiach książki oddalamy się od bezpośredniej lokalności, by zyskać wgląd w administracyjno-prawne aspekty wykopywania maczużnika i obrotu nim. Fluktuacje w odgórnym zarządzaniu yartsą były funkcją różnych polityk, w pierwszym rzędzie ekologicznej. Chiny, w których ziemia uprawna stanowi bodaj tylko $12 \%$ terytorium, podejmują ogromne kampanie przeciwko pustynnieniu i erozji gleb (niejednoznacznie zresztą oceniane przez ekspertów). Władze stoją tu wobec dylematu: jak pasterze mają sobie zapewnić przeżycie, skoro zarówno intensywny wypas, jak i niekontrolowane rozkopywanie ziemi nie służą retencji wody, powodują degradację gleb, obniżając skuteczność programowego „ekologicznego ucywilizowania”. Stąd zatem - oprotestowywana na różne sposoby przez ludność - wielość i zmienność decyzji administracyjnych, regulujących (ograniczających i dopuszczających) pozyskiwanie grzyba, także przez wymóg licencji dla zbieraczy chińskich pracujących u Goloków - na ich gruntach i w końcowym efekcie na ich rzecz. Skądinąd, zważywszy liczebność tych sezonowych migrantów, także oni stanowią zagrożenie dla gospodarzy terenu: „co możesz zrobić, kiedy nagle, w środku nocy, przyjeżdża grupa 180 mężczyzn na motorach?” (s. 163), a też gdy taka grupa kopie yartsę bez zgody posiadacza praw użytkowych do terenu, a zarazem wbrew odgórnemu prawu. W tym kontekście autorka dokonuje uszczegółowień teoretycznych, rozróżniając postępowanie nielegalne (z punktu widzenia prawa) od zachowań niedopuszczalnych (z punktu widzenia pasterzy, illicit). Przedstawia sytuacje ich przecinania się i nakładania, przytaczając swoje obserwacje codziennych przejawów tych konfliktów i przyziemnych form ich negocjowania.

Wszystkie takie okoliczności, zwłaszcza te budzące niezadowolenie Tybetańczyków, skutkowały zmiennością regulacji i niekonsekwentnym, miękkim ich egzekwowaniem (w postaci łatwych do ominięcia praktyk kontroli). Nadrzędną racją władz było bowiem zachowanie spokoju społecznego. „W Goloku - podsumowuje autorka - legitymacja władzy (wszelkiego poziomu) nie jest kwestionowana z zasady i na stałe, ale raczej w kontekście szczególnie niepopularnych decyzji politycznych, idących wbrew interesowi ludności” (s. 166).

Trzeba jeszcze raz podkreślić, że wszystkie te spostrzeżenia umieszczone są na tle całościowo potraktowanego, precyzyjnie udokumentowanego i szczegółowo opisanego bytowania pasterskich rodzin, zwłaszcza w jego aspekcie ekonomicznym, rynkowym (przychody, zakupy, inwestowanie w nowe domy). Książka to nie tylko studium fenomenu ekonomicznego, ale i monografia pewnej lokalnej formy pasterskiego życia dzisiaj. Autorka notuje przy tym najróżniejsze ukryte przepływy i przemiany, np. jak zbieranie grzyba zmusza do rezygnacji z bardziej czasochłonnych specjalności w obrębie pasterstwa - stąd „znikanie owiec” i pozostawanie przy jakach, które „pasą się same”. Wpływa to na poczucie tożsamości, jakie deklarują Golokowie, którzy - pamiętając przecież, jacy byli całkiem niedawno - sami siebie oskarżają o to, że stali się „pasterzami leniwymi”. 
Uwadze autorki nie uchodzą imponderabilia, np. kwestia jakościowego (nieabstrakcyjnego) charakteru pieniądza. Nie potwierdza pochopnie sugestii innych badaczy, którzy stwierdzali odmienne traktowanie pieniędzy zarobionych "na grzechu” - w sposób potępiany czy nietypowy (trzeba pamiętać, że wszelkie naruszanie ziemi jest w tybetańskim buddyzmie traktowane nader krytycznie). Chociaż i tu pasterze deklarowali niekiedy, że sumy uzyskane z tego okazjonalnego źródła przeznaczają czasem na inne, bardziej doraźne cele niż przychody z zasadniczego pasterstwa, to taka dyskryminacja byłaby trudna do utrzymania, zważywszy że te niestandardowe przychody wielokrotnie przekraczają owe tradycyjne.

$\mathrm{W}$ różnych miejscach książki uwidacznia się wieloaspektowe uwikłanie yartsy w duchowość buddyjskich Tybetańczyków, co tworzy takie oto ogólniejsze tło: pasterze nie mogą wprawdzie uniknąć zabijania swoich zwierząt, starają się jednak je ograniczać, np. do sztuk „powypadkowych”, a dziś także przez kupowanie gotowego mięsa w sklepach, za pieniądze właśnie ze sprzedaży yartsy. Niejednokrotnie deklarowano zaprzestanie sprzedawania jaków do rzeźni - na tę wielkoduszność można sobie pozwolić dzięki tym samym pieniądzom; upowszechniają się też wyrzeczenia jego spożywania w ogóle. W odniesieniu do wykopywania grzyba wyrażano przekonanie, że naruszanie ziemi i czerpanie korzyści z wydobywania czegoś na terenach położonych w świętych okolicach góry Amnye Machen musi powodować ubytki w życiodajnej mocy czy esencji (tyb. sabchud), gwarantowanej przez ową górę i jej duchowych mieszkańców. Nagłe wzbogacanie się też ma w sobie coś moralnie podejrzanego, zwłaszcza jeśli nie towarzyszy temu - jak skarżą się lamowie - zwiększona hojność wobec funkcjonariuszy religii. Częściową rekompensatą są ofiary składane z intencją uniknięcia porażki w nieprzewidywalnych transakcjach czy zapobieżenia załamaniu koniunktury. Powstrzymywanie się od kopania w pewne dni jest częściej powodowane złymi warunkami pogodowymi aniżeli religijną tabuizacją dni przełomowych wedle buddyjskiego kalendarza lunarnego.

Ostatnie strony książki noszą wprawdzie solenny tytuł Nota metodologiczna, ale w istocie mają inny, bardzo osobisty charakter. Autorka w ujmujący sposób ukazuje tu swoje nieoficjalne oblicze, rezygnując z gładkości, jaką nadawał akademicki dyskurs, i odsłaniając tę niewygładzoną rzeczywistość, w której tak naprawdę funkcjonowała: bez jakiegokolwiek oficjalnego statusu, na przeważnie własnym, skromnym finansowaniu („moi rozmówcy współczuli mi i oferowali pieniądze, $\mathrm{z}$ ich perspektywy byłam biedna jak mysz kościelna"), chodząc piechotą i ledwie łapiąc oddech w tym wysoko położonym terenie (a nie przyjeżdżając SUV-em, jak afiliowani badacze), okrzykując się od agresywnych psów, bez oficjalnego zezwolenia władz, a więc ryzykując w każdej chwili wydalenie - czyli nieodwołalne przerwanie badań i krach życiowego projektu. Nawet jej fizyczność nie była imponująca, ku zaskoczeniu miejscowych. Ale wszystkie te okoliczności tylko zbliżyły ją do ludzi, niwelując tak częsty dystans i dominację badacza: „to że jestem niewysoka [podobnie jak rozmówcy], działało na moją korzyść" (s. 273-274). Wprawdzie łatwo byłoby recenzentowi powiedzieć tu okrągłe słowa, że w sumie to ubóstwo miało zatem swoje dobre strony, ale wolę wyrazić swoje uznanie - zarówno dla hartu ducha badaczki w terenie, jak i dla rzadko spotykanej w druku, nieupiększonej szczerości autorki.

Obowiązkiem recenzenta jest zapytać na koniec, czy w tak obszernej pracy czegoś nie zabrakło. Nie mam do autorki pretensji, że nie uwzględniła w książce perspektywy transgatunkowej, asamblażów ludzko-nieludzkich, grzybowej sprawczości itp. Ostatecznie yartsa to nie to samo co wspomniany matsutake; czytelnik może zresztą sam próbować interpretować materiał terenowy w ten sposób. Z oczywistych względów chronologicznych nie ma też w książce takiego epilogu, który pokazałby, co dzieje się, kiedy tytułowy boom nagle się kończy. Autorka zadaje to pytanie, tak jak stawiała je w terenie, roztrząsając z rozmówcami tę kwestię, wtedy jeszcze nieaktualną. Wówczas ich odpowiedzi miały charakter niezobowiązujących przypuszczeń, załamanie cen nastąpiło bowiem już po ukończeniu książki - było ono wywołane decyzjami władzy centralnej, zmierzającymi do ukrócenia korupcji poprzez zakaz przyjmowania kosztownych prezentów, a to bodaj ta właśnie praktyka szczególnie nakręcała ceny.

No cóż, można powiedzieć, że o ile z reguły etnograf zaczyna swe badania, kiedy już jest za późno, to tym razem za wcześnie je skończył; może tylko nie jest jeszcze za późno, by ten wątek kontynuować. 
Druga omawiana tu pozycja przenosi nas do nieodległego Sinciangu i w jeszcze większym stopniu traktuje o relacjach między tym, co własne, lokalne i podporządkowane, a tym, co obce, centralne i dominujące - o chińskich oddziaływaniach na ujgurskim gruncie. The Great Dispossession. Uyghurs between Civilizations (2020) to ostatnia książka autorów dobrze nam znanych: Chris Hann - tu wespół z żoną, Ildikó Bellér-Hann, turkolożką z wykształcenia - to przecież długoletni dyrektor Max Planck Institute for Social Anthropology w Halle, który zrobił wiele zarówno dla upowszechnienia polskiej problematyki, jak i dla wprowadzenia młodych polskich antropologów w środowiska nauki zachodniej. Niniejsza publikacja dopełnia obszerny cykl studiów obojga autorów poświęconych sytuacji społeczno-ekonomicznej obszarów postsocjalistycznych (w przypadku Chin trzeba szukać innych terminów: mamy ich do wyboru całą paletę - od „neosocjalizmu” po „państwowy kapitalizm”). Niewykluczone, że będzie to ostatnia pozycja wydana pod egidą Instytutu w Halle - wypada może wspomnieć, że po ćwierćwieczu prowadzenia go Chris wraca do swojego macierzystego kolegium Corpus Christi w Cambridge.

Już sam tytuł nie pozostawia w czytelniku wątpliwości, że publikacja będzie surową oceną chińskiej obecności w Sinciangu. Tak to widzą badacze, którzy bywali tam kilkakrotnie w przeciągu minionych 35 lat (także stacjonarnie, po wiele miesięcy), obserwując, jak kolejne zwroty polityczne odbijały się na życiu ujgurskiej społeczności. Od razu trzeba zauważyć, że dłuższe pobyty miały miejsce, zanim jeszcze ludność ta została dotknięta represjami ostatnich kilku lat, a zatem obraz wynikający z własnych pogłębionych badań musiał zostać uzupełniony o spostrzeżenia przelotne i doniesienia publicystyczne. Niektóre sądy autorów są zatem formułowane raczej z tej nowszej, zaktualizowanej perspektywy, niekoniecznie $\mathrm{z}$ własnego oglądu.

Książka nie jest syntezą, składa się bowiem na nią kilkanaście artykułów (już znanych, ale przeredagowanych), przeważnie indywidualnie podpisanych przez autorów. Rozdziały ramowe („Wstęp” i „Epilog”), napisane przez nich wspólnie, zawierają rozwinięcie i uzasadnienie obu terminów kluczowych, użytych w tytule. „Cywilizacja” - słowo nieczęsto stosowane dziś w naszej dyscyplinie, choć odżywające w ramach studiów nad Eurazją - sygnalizuje tu, że Ujgurzy Sinciangu będą zaliczeni do oddzielnej formacji kulturowej: obszaru turkojęzycznego islamu.

To właśnie cywilizacyjne spotkanie chińsko-muzułmańskie, obserwowane w skali lokalnej, głównie we wsiach i miasteczkach oazy Qumul (bardziej znanej pod chińską nazwą Hami), jest przedmiotem tej książki. Jak sugeruje drugi mocny użyty w tytule termin, Dispossession, nie jest to bynajmniej spotkanie równoprawne. „Wywłaszczenie” oznacza tu coś innego niż usunięcie z zajmowanych domów i gruntów. Choć i takie przewłaszczenia miewały miejsce za sprawą obrotnych chińskich spekulantów i inwestorów, to przecież ocena autorów dotyczy destrukcyjnych zmian w całokształcie ujgurskiego dziedzictwa - likwidacji dotychczasowych form bytowania, praktyk społecznych i systemów symbolicznych. Byłoby to zatem całościowe „wywłaszczenie moralne” - tego terminu już wcześniej użył Chris Hann w książce pod redakcją Ildikó Bellér-Hann (Brox, Bellér-Hann 2014), do której jeszcze wrócę.

Zebrane artykuły nie są tylko przyczynkami, omawiają bowiem w sumie trzy zasadnicze kompleksy zagadnień: kwestie tożsamościowe w perspektywie historycznej (autorstwa IB-H) ${ }^{1}$, sytuację społeczno-ekonomiczną oraz relacje między religią a polityką (przemiennie oboje autorzy). W części pierwszej autorka pokazuje w kilku analizach poszczególnych przekazów dokumentalnych, że w opozycji do chińskocentrycznej wizji dziejów Sinciangu powstawały w przeszłości - i nadal funkcjonują - oddolne narracje na temat lokalnych epizodów w historii Ujgurów (skądinąd trzeba pamiętać, że ten etnonim, choć nawiązujący do dostojnej przeszłości, upowszechnił się dopiero za czasów ChRL, uniwersalizując wcześniejszą identyfikację lokalną - $\mathrm{z}$ daną oazą). Przybliża i analizuje różne zapisy (utrwalona na piśmie tradycja ustna, legendy), które wprowadzają w klimat historyczny, w relacje władzy i podległości, w świat małych bohaterów lokalnej przeszłości. Przez owe teksty przekazywane jest pewne imaginarium wzorów i charakterów składających się na wyobrażenie własnej tożsamości.

${ }^{1}$ Referując kolejne rozdziały, pozwolę sobie używać niekiedy akronimów CH i IB-H, by uniknąć ciągłego powtarzania nazwisk obojga autorów. 
W drugiej części książki („Wsparcie społeczne i gospodarka”) zawarte są studia składające się na obraz ekonomicznego funkcjonowania ujgurskiej wsi i jego związku z mechanizmami zabezpieczeń społecznych. Te ostatnie są szczególnie istotne w warunkach wdrażanej gospodarki rynkowej ze wszystkimi jej zagrożeniami. Niezależnie od tego, że instytucje administracji państwowej zapewniają wsparcie dla najuboższych, zorganizowana jest też opieka medyczna, to nadal dobrze funkcjonują religijne praktyki charytatywne (mimo że teoretycznie islamski podatek zakat został zniesiony). Autorzy opisują w szczegółach, jak wygląda nieodpłatna współpraca w niektórych działaniach gospodarczych (wręcz obligatoryjna przy budowie domu), wynagradzana - zwłaszcza we wsiach górskich - wyłącznie na zasadzie uogólnionej wzajemności. Także pomoc w potrzebie udzielana jest $\mathrm{w}$ ramach więzi sąsiedzkich i krewniaczych, utrwalanych przez stosowne rytuały. Dobroczynność i hojność są nadal elementem ujgurskiego wizerunku własnego, samooceny i prestiżu. Bolesny paradoks polega więc na tym, że ten sam islam, organizujący ujgurską „moralną ekonomię, jest celem politycznych ataków w ramach „walki $z$ fundamentalizmem, separatyzmem i terrorem”.

Jak zaznaczyłem, książka nie relacjonuje owej „walki”, jaka - w obecnej odsłonie -toczy się od ponad dziesięciolecia, a raczej przedstawia tło społeczne, na którym formują się aktualne wydarzenia. Przyspieszony rozwój ekonomiczny Chin dotknął w pewnym stopniu także Sinkiang, objęty, wraz z Tybetem, kampanią Otworzyć Zachód. Modernizacyjna polityka wychodziła z założenia, że na fali ogólnego bogacenia się dojdzie do wyrównania standardów, a tym samym znikną powody animozji etnicznych między Ujgurami a przybywającymi coraz liczniej Chińczykami Han. Nadzieje władz, że sukces materialny usatysfakcjonuje biedniejszą ludność wiejską, nie spełniły się, bo ten sukces nie stał się równym udziałem wszystkich. Owszem, nastąpił wzrost poziomu życia, ale też towarzyszyła mu frustracja, że napływowa ludność chińska zyskała jeszcze więcej, a drogi awansu dla miejscowych są praktycznie zablokowane.

Tak jak przedstawia to $\mathrm{CH}$, zasadniczy problem polega na tym, że niemożliwe jest równoprawne uczestnictwo Ujgurów w ogólnym bogaceniu się w warunkach gospodarki rynkowej, kiedy przychodzi konkurować z dominującą - politycznie, kompetencyjnie, a nawet liczebnie - ludnością napływową. Zacząć wypada od kwestii języka, która ma tu znaczenie zasadnicze. Autor powraca do swej wcześniejszej, wzmiankowanej powyżej publikacji (Hann 2014), gdzie przedstawił szerszą perspektywę: przywołuje sąd swego mistrza, Ernesta Gellnera, który, analizując epokę nowoczesności w państwach środkowoeuropejskich, wskazywał na rolę ujednolicenia językowego w tym projekcie. Choćby ze względu na to, że wdrożenie industrialności wymaga zaawansowanego kształcenia szerokich mas, wygrywa opcja likwidowania różnic językowych; w efekcie dochodzi do językowej (a też etnicznej, narodowej) hegemonii. Jakby to dziwnie nie zabrzmiało, wieloetniczne Chiny postawiły natomiast na harmonię: uznanie odrębnego statusu mniejszości, a zatem i dwujęzyczność w edukacji. Jednak w praktyce oznaczało to pozostawanie Ujgurów przy własnym języku, tym bardziej że hasłowe dowartościowanie etnosu dało im moralną siłę do trwania przy nim. Jeśli dodać do tego inne szczegółowo omówione powody (nawet wzajemnie sprzeczne: niekompetencja nauczycieli i słabości procesu nauczania języka versus poczucie narzucania go), to nic dziwnego, że konsekwencją jest słaba znajomość chińskiego wśród Ujgurów, a zatem mniejsze ich szanse w rynkowej rywalizacji, niedostatki językowe są bowiem $\mathrm{z}$ reguły dobrym pretekstem do dyskwalifikacji, np. w staraniach o pracę.

Ale mimo to zachowanie odrębności etnicznej nie jest w tych warunkach oczywistością. I nie chodzi tu tylko o przymusowe działania wykorzeniające ze strony aparatu państwowego, ale raczej o procesy kulturowej asymilacji, zwłaszcza elit w ośrodkach miejskich. Zanik ważności etnicznej differentia specifica wydaje się niektórym chińskim badaczom zarówno nieunikniony, jak i pożądany. $\mathrm{CH}$ przywołuje koncepcję wpływowego socjologa Ma Ronga, wedle którego w nowoczesnych realiach gospodarczych etniczność nie ma znaczenia produkcyjno-rynkowego, jako że „niewidzialna ręka rynku” anuluje czy zaciera ważność tamtych zróżnicowań, zatem zbyteczne są akcje afirmacyjne i odgórne podtrzymywanie odrębności.

W lekturze artykułów poświęconych gospodarstwu wiejskiemu uwagę zwracają ciekawe generalizacje autorów, wplecione w szczegółowy tekst opisowy, takie jak ta, że wieś subsydiuje miasto, 
mianowicie dożywiając domowymi zasobami swoich migrantów pracujących na rzecz indywidualnych przedsiębiorców. Jako „kolonizację” czy wręcz eksploatację CH traktuje wymuszoną monetaryzację gospodarstw domowych - niegdyś autarkicznych, samożywieniowych, obecnie zmuszonych do pozyskiwania gotówki przez dodatkową pracę najemną albo przez uprawę roślin produkowanych do skupu (cash crops - bawełna, soja). Dokonuje się ona gwoli zaspokojenia wyśrubowanych standardów finansowych w przypadku obrzędów (zwłaszcza weselnych) albo dla pokrycia kosztów lepszego ubezpieczenia zdrowotnego, dostępnego dla mieszkańców wsi za opłatą. W sumie wymagane od ujgurskich rolników nastawienie rynkowe godzi w ich ekonomię samowystarczalności, $\mathrm{w}$ dotychczasowe formy bytowania. Wszystko to nie daje satysfakcji uczestnikom gry rynkowej, stając się podłożem obaw i frustracji.

Trzecia część książki jest poświęcona obszarowi ujgurskiej duchowości, znów w aspekcie nieuniknionego jej uwikłania w politykę. Siłą rzeczy przedstawiony tu materiał ma znacznie mocniejszą wymowę: w sferze duchowej, religijnej, dużo bardziej niż w kwestiach wiejskiego gospodarowania zależy władzom na absolutnej kontroli, zarówno przestrzeni i zawartego w niej etnicznego dziedzictwa, jak i ludzkich działań i umysłów.

Na początku tej części zostajemy wprowadzeni w pejzaż kulturowy niby-historycznego centrum oazy Qumul/Hami. IB-H znakomicie, z wzorową uważnością i precyzją analityczną, odnotowuje ponurą groteskowość tego sztucznego konstruktu, który został stworzony zupełnie niedawno, by zastąpić autentyczną tkankę kulturową. Na miejscu wyburzonego cmentarza wzniesiono pseudozabytkowy wymyślony pałac ujgurskiego władcy w pokazowo chińskim stylu, a cementowe dinozaury pomalowane na fioletowo stoją przy absurdalnie przeskalowanych pomnikach ludowych instrumentów muzycznych. Autorka nader trafnie opatruje te niby-kulturowe produkty mianem "potiomkinowsko-disneyowskich” (ja sam, stykając się z tego typu „wyrobami kulturopodobnymi” także na innych obszarach Chin i Azji Środkowej, używam określenia „wydmuszka”), a całą tę politykę określa mianem „twórczej destrukcji”.

W odniesieniu do religii sensu stricte ten wieloletni okres, w którym autorzy wizytowali Sinciang, oznaczał dla całych Chin liberalizację, a wobec tak szczególnej formy, jak konfucjanizm - wręcz awansowanie jego elementów do pozycji nieledwie ideologii państwowej. Na badanym obszarze to ostatnie nie mogło z oczywistych powodów mieć miejsca; tutejszy islam był dopuszczony, acz kontrolowany i limitowany w sposób w delikatny: zanim jeszcze proklamowano „ludową walkę z islamskim terrorem”, prowadzono politykę udomowienia religii, tzn. odebrania ceremoniom charakteru publicznego i przeniesienia ich w obszar domowy. Tylko dwa podstawowe święta w islamskim cyklu rocznym mogły być obchodzone publicznie; władza dba o to, by Noruz - środkowoazjatycki Nowy Rok - był obchodzony bardzo widowiskowo, ale bez żadnych elementów religijnych; funkcjonariuszy państwa (łącznie z nauczycielami) obejmuje zakaz uczestniczenia w kulcie itd.

Uogólniając te analizy, można powiedzieć, że władze starają się osłabić islam (który mimo to odgrywa decydującą rolę w utrzymaniu zbiorowej spoistości grupy), kontrolować go i sekularyzować, tak modyfikując formy jego wyrazu, by były jednym z przejawów świeckiej tożsamości obywatelskiej. $\mathrm{Z}$ drugiej strony $\mathrm{CH}$ wskazuje też takie fakty, jak to, że zbiorowe pielgrzymki do Mekki są organizowane i subsydiowane przez państwo, co zresztą ma sens kontrolny - indywidualne wyjazdy są „stanowczo odradzane"; na marginesie - powracając na chwilę do kwestii jakościowej niejednakowości pieniądza - odnotuję spostrzeżenie autora, iż w rodzinach pielgrzymów dba się o to, by fundusze, przeznaczane na ten cel, pochodziły wyłącznie ze źródeł moralnie „czystych”.

W badanych wsiach autorzy nie zetknęli się już z postaciami typu szamańskiego ani znachorskiego, ale przywołują niedawne opracowania, mówiące o funkcjonowaniu nieopodal praktyki zaklinania deszczu yada. Jest to procedura zislamizowana, sprawowania jako zbiorowa modlitwa proszalna, aczkolwiek z wykorzystaniem końskiej czaszki, a nawet węży. Ze swej strony zauważę, że nie pojawia się tu słynny w całej Azji Środkowej kamień deszczowy, yad - z reguły kamień włosowy, znany w Europie jako bezoar. W ocenie autorów rytuał ten nie budzi zainteresowania wśród ujgurskiej młodzieży. Jego przyszłością mogłoby być skomercjalizowanie go i pokazywanie turystom (!). Szkopuł w tym, że z powodów naturalnych praktykuje się go tylko w odległych wsiach pasterskich, uzależnionych od opadów, podczas gdy wsie nizinne korzystają z centralnych rezerwuarów. Piszę o tym wszystkim 
z żalem, jako że sam zetknąłem się jeszcze niedawno z żywym, autentycznym funkcjonowaniem kamienia deszczowego zadyn čuluu i jego magii w Mongolii: zarówno u nieodległych od Sinciangu Torgutów, jak i wśród tajgowych Tucha (Caatanów), czyli na północnych peryferiach obszaru turkijskiego w Azji Centralnej.

Jak uprzedzałem, książka nie jest syntezą - nie każdy ważny aspekt ujgurskiego bytowania jest w niej poruszony. Ciekaw byłbym relacji o tym, jak wygląda oddolny udział w walce z pustynią, która to aktywność (prowadzona odgórnie) jest zauważalna nawet przy przelotnym tam pobycie, by nie rzec, że jest imponująca. Przydałyby się też informacje na temat polityki ekologicznej w stosunku do pasterzy - obwinianych tu, podobnie jak w Tybecie, o nadmierny wypas.

Wieńczący pracę „Epilog” odwołuje się do pobytu późniejszego niż w przypadku pozostałych tekstów - do krótkiej wizyty w 2013 roku, a więc już w trakcie nasilenia „ludowej walki z terrorem” (czytaj: urzędowych prześladowań, obozów pracy i reedukacji). Ten pobyt nie mógł mieć charakteru badawczego - wiązałoby się to z narażaniem starych znajomych na groźne konsekwencje - charakter krótkiej relacji jest zatem inny: autorzy dokonują ogólnego, a niewesołego bilansu chińskiej hegemonii. $\mathrm{W}$ ich ocenie napięcia między obiema grupami w badanym przedziale czasu wzrosły - wbrew urzędowym nadziejom, że dwujęzyczna edukacja doprowadzi do społecznej harmonizacji. Wsie zostały widocznie zmodernizowane, przeobrażając się w standardowe, asfaltowo-cementowe miasteczka, gdzie mieszkania udostępniane są Ujgurom za 10\% wartości, a i to na raty. Jednak w ocenie autorów nie wszyscy mieszkańcy - a niektórzy zostali przesiedleni z wyżej położonych pastwisk - odnajdą się w nowej miejskiej przestrzeni, z wyodrębnionymi od domostw mieszkalnych, oddzielnie zgrupowanymi budynkami dla zwierząt i z niemuzułmańskimi toaletami. Efektem dwujęzycznej edukacji $\mathrm{w}$ warunkach braku realnych perspektyw karier dla miejscowych będzie raczej frustracja: rodzicielskie nadzieje na karierę dzieci poprzez dodatkowe indywidualne inwestowanie w ich naukę okazują się nie mieć uzasadnienia, a mobilność, na którą bardzo liczyli młodzi, okazuje się złudą, albowiem praca w większych miastach jest dostępna praktycznie tylko dla Hanów. Konkludując: u podłoża okazjonalnych erupcji wrogości (które dały władzy asumpt do zaostrzenia kursu) leżą nie inherentne animozje etniczne, różnice kulturowo-religijne czy ewentualne prześladowania ze strony władzy, ale raczej zawiedzione nadzieje w warunkach zablokowanych szans wzrostu własnego („pułapka średniego rozwoju”) w kontraście do obserwowanego awansu obcych zalewających region w coraz większym stopniu. Wniosek wcześniejszego artykułu CH pozostaje zatem w mocy: „Dane z ostatnich dekad sugerują, że deklarowany cel władz - tworzenie harmonijnego społeczeństwa - może być niekompatybilny z ich celem ukrytym, którym jest budowanie społeczeństwa zhomogenizowanego. Trzeba będzie zrezygnować albo z jednego, albo z drugiego" (Hann 2014, s. 205).

Ostatnie zdanie książki, podsumowujące passus o odgórnym przerzucaniu ujgurskiej „siły roboczej” w różne regiony, w tym do obozów pracy, ale też sumujące całą publikację, brzmi wyjątkowo posępnie: „To wcale nie jest rozwój, ale jeszcze jeden element wszechogarniającego cywilizacyjnego wywłaszczenia” (s. 242). Czy naprawdę taki ma być historyczny efekt konfrontacji chińskiego buldożera $\mathrm{z}$ całą formacją cywilizacyjną turkojęzycznego islamu?

Czytając wcześniej zbierane partie materiału, dotyczące wiejskiego gospodarowania, czytelnik mógł mieć jeszcze nadzieję, że chińska hegemonia nie musi oznaczać kulturowej dewastacji Turkiestanu, choć niektóre odgórne przedsięwzięcia modernizacyjne napotykały lokalnie na pewien, jak to formułują autorzy, sceptycyzm. W terenie nie ujawniał się w ogóle konflikt ściśle etniczny, ale raczej wspomniane obawy i niezadowolenie spowodowane niemożnością realizacji spodziewanego awansu. Pewna niekompatybilność pomiędzy wymową ekonomicznej części starszego materiału a pesymistyczną oceną zawartą w „Epilogu” (i w ostatecznym tytule) ma różne powody. Najpoważniejszy z nich to okoliczność, że tamte materiały zostały pozyskane, zanim jeszcze Sinciang ogarnęła fala masowych represji, podczas gdy podsumowujące komentarze były pisane już w trakcie ich trwania, w bezpośredniej na nie reakcji.

Zauważę też, że niełatwo jest osiągnąć harmonię między deklaracjami wstępnymi, wymową świadectw terenowych i generalizacjami podsumowań. Widać to we wspomnianej już pracy zbio- 
rowej, poświęconej obu omawianym terenom, współredagowanej przez Ildikó (Brox, Bellér-Hann 2014). Redaktorki odżegnują się we wstępie od zero-jedynkowego ujmowania relacji między mieszkańcami a chińskimi władzami (co doceniają publikowane recenzje ich książki), ale w każdym ze studiów szczegółowych ich autorzy reprezentują twardą linię. Oddam głos krytycznemu recenzentowi tego zbioru (bynajmniej nie Chińczykowi): „Prawie każdy rozdział zaczyna się i kończy sloganem-mantrą - rytualnym scharakteryzowaniem Tybetu i Sinciangu jako «obszarów mniejszościowych, uciśnionych politycznie». Wbrew deklaracjom redaktorek ze «Wstępu», autorzy rozdziałów gorliwie szukają konfliktu etnicznego i - nic w tym dziwnego - prawie zawsze go znajdują" (Jacobs 2015, s. 203).

Czyżby zatem nasz obraz cierpiącego Tybetu i Turkiestanu był, o ironio, nowym fantazmatem? Odpowiedź na to pytanie, a nawet sama ta kwestia, będzie różnie wyglądać w odniesieniu do obu terenów i obu przedstawianych tu publikacji. O ile w pierwszym referowanym przypadku, tybetańskim, ów ucisk etniczny rzeczywiście nie był widoczny, to przecież trudno zgodzić się na taki sam werdykt w kontekście masowych deportacji Ujgurów do obozów pracy czy choćby polityki hegemonii i asymilacji.

Niech mi będzie wolno zrobić na koniec odległą dygresję i przytoczyć własną obserwację z krótkiego pobytu w Sinciangu w 2013 roku. Spotykając się tam z miejscowymi Mongołami, zauważałem jak sinizowane są ich imiona/nazwiska. Bujanchüü stawał się w chińskim dowodzie osobistym Buu Yan choo, a Tenger zmieniał się w Deng ger; brzmiało to po chińsku, ale kompletnie zacierało oryginalne, bogate znaczenie tych słów (mongolskie bujan chüü - dobroczynny syn, tenger - niebo). Oczywiście, trudno było mi nie obwiniać władzy o świadome wynarodowianie - aż do niedawnego konkursu chopinowskiego, kiedy to, jak widzieliśmy, chińskie imię jego zwycięzcy, Liu Xiaoyu, nie miało szans na przyswojenie w innej postaci aniżeli pamiętny „Bruce Lee”, co przecież nie było zamierzoną dyskryminacją.

Zasadnicza różnica $\mathrm{w}$ ocenie obu tych sytuacji polega $\mathrm{z}$ pewnością na tym, że odbywały się w zupełnie innym kontekście politycznym: prześladowania Ujgurów każą uważnie patrzeć na tamtejsze działania asymilacyjne, chociaż w obu wypadkach trwają podobne procesy językowej homogenizacji i podporządkowania.

\section{LITERATURA}

Brox Trine, Bellér-Han n Ildikó (red.) 2014, On the Fringes of the Harmonious Society. Tibetans and Uyghurs in Socialist China, Nordic Institute of Asian Studies, Copenhagen.

$\mathrm{H}$ a n n C h r is 2014, Harmonious or Homogenious? Language, Education and Social Mobility in Rural Uyghur Society, [w:] Trine Brox, Ildikó Bellér-Hann (red.), On the Fringes of the Harmonious Society. Tibetans and Uyghurs in Socialist China, Nordic Institute of Asian Studies, Copenhagen, s. 183-208.

Han n Chris, B ellér - Han n Ild i kó 2020, The Great Dispossession. Uyghurs between Civilizations, Halle Studies in the Anthropology of Eurasia, LIT Verlag, Berlin, Münster.

Ja c o b s J u s t i n M. 2015, recenzja książki Brox Trine, Bellér-Hann Ildikó (red.) 2014, On the Fringes of the Harmonious Society. Tibetans and Uyghurs in Socialist China, The China Journal, nr 74, s. 203-205.

R a kow sk i To m as z 2009, Łowcy, zbieracze, praktycy niemocy. Studium człowieka zdegradowanego, Wydawnictwo słowo/obraz terytoria, Gdańsk.

R a kow ski To m a s z 2019, Przeplywy, współdziałania, kręgi możliwego, Wydawnictwo słowo/obraz terytoria, Gdańsk.

Sulek Emilia Roza 2019, Trading Caterpillar Fungus in Tibet. When Economic Boom Hits Rural Area, Amsterdam University Press, Amsterdam.

Tsing Anna Lowen haupt 2015, The Mushroom at the End of the World: On the Possibility of Life in Capitalist Ruins, Princeton University Press.

Wa s s o n R o be r t Gord on 1972, Soma Divine Mushroom of Immortality, Sungazer Press, New York. 